\title{
PENDIDIKAN IMAN, KARAKTER SERTA PENDEKATAN KONSELING DALAM PENGENDALIAN DIRI
}

\section{Resti Kinda}

Lembaga: IAKN Toraja, posel: Kindaresti@gmail.com

\begin{abstract}
Abstrak: Kajian dalam tulisan ini hendak membahas mengenai pendidikan yang membentuk karakter seseorang serta iman dan pengendalian diri dalam pengembanga pendidikan kristiani. Di zaman sekarang ini, pendidikan sangat dibutuhkan untuk membentuk karakter seseorang baik dalam mempertahankan imannya serta untuk mengendalikan diri dari berbagai problematika yang terjadi. Iman kristen merupakan suatu kepercayaan kepada Kristus Yesus yang harus kita miliki. Pendekatan konseling juga merupakan bentuk perhatian yang diberikan terhadap orang-orang termasuk anak dalam mendidik mereka untuk menyikapi perkembangan di era teknologi digital.
\end{abstract}

Kata kunci: pendidikan iman, karakter, pendekatan konseling, pengendalian diri

\section{Pendahuluan}

Pendidikan iman sejatinya bukan satu-satunya diperoleh melalui pendekatan sekolah formal. Fakta adalah iman lebih dominan diperoleh justru melalui budaya; dan secara konkrit lebih banyak melalui keteladanan dan interelasi individual. Dengan kata lain, kepercayaan atau iman lebih dipengaruhi melalui pembentukan kultur. ${ }^{1}$

Karakter merupakan suatu pembawaan individu yang merupakan sifat, kepribadian, watak serta tingkah laku yang merupakan jati diri yang dilakukan di dalam kehidupan. Setiap orang harus memilki katakter yang baik agar ia menjadi pribadi yang berkualitas, cerdas dan bertanggung jawab. Perlu juga adanya pendekatan atau bimbingan konseling bagi setiap orang agar memberi mereka bimbingan melalui pendekatan pribadi dalam meyelesaikan masalahnya.

\footnotetext{
${ }^{1}$ Rannu Sanderan, "Exemplary Menemukenali Kunci Pendidikan Iman bagi Anak dalam Keluarga dan Pembelajaran Agama di Sekolah," 3 Jurnal PAK_ganjil 2016_2017_EXEMPLARY docx, version 1 (November 19, 2021): 1, https://osf.io/bmtrk/
} 
Tujuan dalam penulisan kajian ini ialah untuk memberikan kita pemahaman mengenai bagaimana pendidikan iman kritiani itu penting dalam membentuk karakter yang baik dalam beperilaku dalam kehidupan sehari-hari serta bagaiaman kita mendisiplinkan diri.

Manfaatnya yaitu supaya kita bisa mengerti dan memahami pendidikan iman bagi anak dan keluarga, serta mengetaui dan belajar melihat karakter dan juga mengerti mengenai pendekatan konseling bagaimana dalam pengendalian diri.

\section{Pembahasan}

\section{Pembentuk karakter dan kepribadian Anak}

Hampir semua ahli pendidikan sepakat bahwa keteladanan dan menirukan adalah alat yang paling ampuh untuk mengajarkan iman secara berulang-ulang. Keteladanan merupakan hal ideal yang dapat diupayakan oleh orang percaya, kendati tidak bersangkut-paut langsung dengan orang-orang percaya di dalam kenyataan.

Karakter dan kepribadian yang dibentuk melalui katalisasi minat dan antusiasme merupakan modal yang besar untuk mencapai/memeroleh sesuatu. Dengan minat seseorang akan memperhatikan sesuatu objek belajar dengan mencurahkan sepenuh-penuhnya kesadaran, tenaga, waktu, peluang dan fasilitas yang dimilikinya demi mendalami objek belajarnya. Karakter dan kepribadian gurulah yang jauh lebih menentukan keadaan murid. Itu artinya, guru sebagai pemberi pengaruh dalam hal akademik memerlukan upaya perawatan karakter dan kepribadian dirinya sebagai yang diteladani. Orang tua juga harus memiliki karakter dan kepribadian yang baik karena Anak-anak seringkali melihat bagaimana orangtua berperilaku dan selanjutnya menirunya perilaku mereka. Alkitab menekankan betapa pentingnya disiplin yang penuh kasih. Orangtua yang tidak menanamkan kedisiplinan terhadap anak remajanya, akan menghadapi akibat-akibat yang dapat menyakitkan dikemudian hari, baik pada diri orang tua maupun pada diri anak itu sendiri. ${ }^{2}$

Pembetukan karakter anak dimulai dari orang-orang terdekat seperti orang tua dan dalam dunia pendidikan seperti guru. Anak dapat mencontoh perilaku mereka dan memprakteknya dalam kehidupannya, untuk itu orang tua maupun guru atau seorang

\footnotetext{
${ }^{2}$ Rannu Sanderan, "Exemplary Menemukenali Kunci Pendidikan Iman bagi Anak dalam Keluarga dan Pembelajaran Agama di Sekolah," 3 Jurnal PAK_ganjil 2016_2017_EXEMPLARY, version 1 (November 19, 2021): 2-4, 9, https://osf.io/bmtrk/
} 
pendidik, pendeta atau gembala harus memberikan dan menanamkan karakter yang baik dalam dirinya karena itulah yang menjadi contoh terhadap orang-orang disekitarnya.

Begitupun juga terbentuknya emosi dan karakter anak-anak Toraja tradisional berkaitan langsung dengan berbagai manifestasi nilai yang mereka rujuk, dan hal ini diadopsi serta ditularkan secara langsung melalui keteladanan. Adapun nilai-nilai etika yang mereka hidupi langsung tersebut antara lain: mengasihi, keadilan, merasa salah, malu, berani, menahan diri, menyimak, mengajukan pendapat, bersekut, dll. Tekanan utama dalam pengembangan karakter secara tradisional berangkat dari nilai luhur konteks budaya lokal. ${ }^{3}$

\section{Pengendalian diri yang benar melalui Alkitab dalam pendidikan iman kristiani}

Pendidikan Kristen dan berbagai bentuk studi kristiani lainnya, sepatutnya membantu siswa sanggup menginterpretasi suatu gambar, menilai suatu keyakinan dan mengevaluasi sendiri nilai-nilai tentang alam dan lingkungan yang terus-menerus ditransmisikan oleh budaya populer. Intuisi yang sehat dan murni dapat menjadi kanal untuk mendidik keluarga dan masyarakat dapat dilakukan dengan berbagai cara dengan mempertimbangkan kebutuhan, usia, dan latar belakang naradidik. ${ }^{4}$

Mengapa manusia seringkali gagal dalam pendidikan? Hal ini terjadi sebab kita cenderung mengembangkan kemitraan yang benar bersifat superior-inferior (atas-bawah), hasil akhir selalu dilematik bahkan tidak jarang konflik. Dengan mengacu kepada dasar Alkitab yang telah dipolakan Yesus Kristus maka, kita memiliki dasar yang kokoh, yakni Kasih, Pendidikan kristiani yang sejati dapat dikembangkan dalam bentuk solidaritas, kerendahan, kesederhanaan, pengosongan diri, pengabdian, pelayanan.

Karena itu tetaplah dipandang sangat penting keterlibatan terhadap segala sesuatu di dunia ini, yakni untuk upaya pengosongan diri dari penggunaan nafsu dan pengendalian keinginan daging, menuju pada peningkatan kualitas moral yang memerlukan pengendalian diri dan disiplin diri serta melatih kesabaran. Kegiatan ini bukan tradisi yang muncul begitu saja, atas dasar pemahaman pribadi terhadap Alkitab.

\footnotetext{
${ }^{3}$ Rannu Sanderan, "Heuristika dalam Pendidikan Karakter Manusia Toraja Tradisional," BIA ': Jurnal Teologi dan Pendidikan Kristen Kontekstual 3, no. 2 (December 19, 2020): 317-318, https://www.jurnalbia.com/index.php/bia/article/view/213

${ }^{4}$ Ranny Sanderan, "INTUISI: Pendalaman Gagasan Hans-George Gadamer Tentang Intuisi Sebagai Supralogika,” Jurnal Ilmiah Religiosty Entity Humanity (JIREH) 2, no. 2 (Desember, 2020): 122, https://ojs-jireh.org/index.php/jireh/article/view/39
} 
Kehidapan Yesus mengisahkan pengendalian daging yang dilakukan dengan kerendahan hati dan kasih kepada Allah serta kepada manusia. Dasar Alkitab asketisme terdapat pada perintah Yesus agar setiap murid-Nya mau menyangkal diri, menjual harta bendanya, dan praktik disiplin juga tampak melalui kebiasaan Yesus mengundurkan diri ke tempat sunyi untuk berdoa. ${ }^{5}$

Ini merupakan proses yang di tunjukkan kepada kita semua yang bisa menjadi pendidikan yang dapat di contoh bagi para murid khusunya kepada kita semua yang berdasarkan perkataan yang fakta atau benar. Dan begitu pentingnya mengendalikan diri dari keinginan daging dan hawa nafsu serta pendidikan kristiani di kembangkan melalu pengabdian dan pelayanan kepada Tuhan, memiliki kerendahan hati agar iman kita bertumbuh di dalam Tuhan.

\section{Pendekatan konseling melalui komunikasi}

Komunikasi konseling merupakan sebuah pelayanan yang bersifat khusus yang sangat dibutuhkan. Secara umun konseling adalah pelayanan bimbingan yang diberikan oleh seorang pembimbing atau konselor terhadap orang yang dibimbing untuk menghadapi dan menyelesaikan masalah pribadinya. Di dalam Alkitab banyak memberikan catatan mengenai pelayanan konseling yang menjadi kunci keberhasilan pemulihan pengaruh buruk yang terjadi dalam kehidupan. Contohnya dalam perjanjian lama di mana Yitro menasehati Musa dalam memimpin bangsa Israel yang besar itu, dan Yitro datang menolong Musa sehingga Musa menemukan hikmat illahi dalam memimpin bangsa Israel. ${ }^{6}$

Saat seseorang mengalami permasalahan dalam hidupnya pendekatan konseling melalui komunikasilah yang merupakan cara dalam memberikan solusi dan menyelesaikan masalah. Sunnguh banyak pergumulan dan permasalahan yang hadapi setiap orang, entah itu dalam keluarga, pekerjaan, dalam lingkungan dan konseling komunikasilah yang merupakan cara yang terbaik yaitu dengan mendengarkan keluh kesah mereka, menasehati mereka dan turut merasakan apa yang mereka rasakan sehingga kita sebagai konselor bisa memberikan solusi dan menyelesaikan masalah terebut.

\footnotetext{
${ }^{5}$ Rannu Sanderan, "Disiplin Asketisme dan Harmoni Kontribusi Disiplin Diri bagi Pengembangan Pendidikan Kriste," 4 Jurnal Pascasarjana PAK 2016_DISIPLIN ASKEPISME DAN HARMONI.docx, Version 1 (November 29, 2021): 3,6, https://osf.io/frsnz/
${ }^{6}$ Samuel Pattipeilohy, Pendekatan Konseling Komunikasi Sebagai Upaya Pemulihan Terhadap Pengaruh Buruk Di Era Digitalisasi, 02 Literasi Digital dalam Perspektif Kristen, (September 2018), 110. https://www.scribd.com/document/510528379/02-Literasi-Digital-dalam-Perspektif-Kristen


Kesimpulan dari pembahasan ini adalah pendidikan iman kristiani yang dimulai dari pengendalian dari berbagai keinginan daging dan hawa nafsu karena dengan itullah iman kita dapat bertumbuh dalam Kristus. Karakter juga sangat dibutuhkan karena seseorang yang mempunyai karakter yang baik akan menjadi pribadi yang baik pula dan membawa pengaruh yang baik pula terhadap sesama dan lingkungan. Juga membutuhkan pendekatan konseling melalui komunikasi yang merupakan suatu cara pendekatakan yang dilakukan untuk menyelesaika masalah pribadi.

Saran yang penulis bisa berikan ialah perlu adanya moteode penelitian yang lebih lanjut mengenai hal ini yaitu bagaiaman pendidikan iman, karakter serta pendekatan Konseling dalam pengendalian diri yang mampu membentuk karakter seseorang atau anak menjadi pribadi yang baik melalui hal tersebut

\section{Daftar Pustaka}

Pattipeilohy, Samuel. Pendekatan Konseling Komunikasi Sebagai Upaya Pemulihan Terhadap Pengaruh Buruk Di Era Digitalisasi, 02 Literasi Digital dalam Perspektif Kristen, September 2018, 110.

Sanderan, Rannu. "Exemplary Menemukenali Kunci Pendidikan Iman bagi Anak dalam Keluarga dan Pembelajaran Agama di Sekolah,” 3 Jurnal PAK_ganjil 2016_2017_EXEMPLARY docx, version 1 (November 19, 2021): 1.

Sanderan,Rannu. "Heuristika dalam Pendidikan Karakter Manusia Toraja Tradisional," BIA': Jurnal Teologi dan Pendidikan Kristen Kontekstual 3, no. 2 (December 19, 2020): 317-318.

Sanderan, Rannu. "INTUISI: Pendalaman Gagasan Hans-George Gadamer Tentang Intuisi Sebagai Supralogika," Jurnal Ilmiah Religiosty Entity Humanity (JIREH) 2, no. 2 (Desember, 2020): 122.

Sanderan, Rannu. "Disiplin Asketisme dan Harmoni Kontribusi Disiplin Diri bagi Pengembangan Pendidikan Kriste," 4 Jurnal Pascasarjana PAK 2016_DISIPLIN ASKEPISME DAN HARMONI.docx, Version 1 (November 29, 2021): 3,6. 